\title{
THE INFLUENCE OF THE INITIAL SOIL MOISTURE CONTENT ON THE DEGREE OF WATER STABLE AGGREGATION AS DETERMINED BY WET SIEVING
}

\author{
MikKo SillanpäÄ \\ Agricultural Research Centre, Department of Soil Science, Helsinki
}

Received July 3, 1959.

A water stable aggregate is considered to be one that has some degree of resistance to breakdown in contact with water and one that does not break down by a given treatment - usually wet sieving $(10,11)$. Because of the lack of clear understanding of the factors and mechanics of stabilization of aggregates in various conditions, no uniform, standardized procedure of sample treatment for determining aggregation has been adopted, but a wide variety of procedures are used. Thus, the results obtained by different investigators cannot often be considered comparable. On the other hand the use of different techniques may be advantagous in studying this behaviour from various angles.

Most investigators allow the soil samples to get air-dry before aggregate analysis but those at field moisture are also often used. Air-drying, no doubt, gives a more uniform initial moisture content of soil samples prior to the aggregate analysis even though it may decrease the amount of larger aggregates in favor of smaller ones $(1,3,8,13)$. The method of wetting the air-dried soil samples prior to aggregate analysis by the wet sieving method very significantly affects the results (12). Especially wetting the samples by direct immersion causes considerably more aggregatedestruction than other slower wetting procedures by capillary action, spraying or in vacuum. This is apparently due to change of pressure of the entrapped air in rapid wetting. The explosive effect of trapped air may be almost so complete that differences in aggregation due to tillage or cropping practice disappear (8). Vacuum wetting cannot be recommended for soils of high clay content because it apparently causes more slaking in these soils than in lighter textured soils $(9,12)$. Since it is obvious that wetting the soil samples for aggregate analyses should correspond as much as possible with natural field conditions, the best methods are wetting by "capillarity" or spray. In both of these methods the penetration of water into the interior of soil aggregates takes place mainly by capillarity, but since the capillary wetting of small samples of various soils is more difficult to do evenly and causes more variation in results than the spraying, the latter seems to be the most recommendable (12). 
When field-moist soil samples are used the degree of change of soil moisture content in wetting varies depending on the original soil moisture condition at the sampling time and apparently also on the wetting method. How much difference in the results of aggregate analyses is due to air-drying field-moist soil and how much is due to re-wetting the soil samples by different methods from the air-dry or from the field-moist condition to saturation cannot be stated. This knowledge is, however, important in choosing the method of sample pre-treatment especially in studying the seasonal variation of aggregation when the soil moisture content alters from time to time. In the investigation of Alderfer (1) the results of the aggregate analyses of the soil samples that were air-dried were completely different from the results of a portion of the same sample that was analyzed at its field-moist condition; in both cases the analysis was made after immersion wetting. The difference in the initial soil moisture content also reversed the results concerning seasonal variation: the maximum aggregation was found during the driest period of the growing season, when analyzing after air-drying while using samples in field moisture condition, the results showed aggregation to be at the minimum during the same dry period. The results of several other investigators concerning the seasonal variatien support those achieved by Alderfer when analyzing soil samples at equal initial moisture content $(2,4,5,6,7)$.

\section{Materials and methods}

A large sample of homogeneous field-moist muddy clay soil from a depth of $10-15 \mathrm{~cm}$ was taken in a plastic container which was sealed air-tight and brought to the laboratory. The particle size distribution and the humus content of the soil were as follows:

\begin{tabular}{|c|c|c|c|c|c|c|c|}
\hline \multirow[b]{2}{*}{$<0.002$} & \multicolumn{6}{|c|}{ Percentage of fraction } & \multirow{2}{*}{$\begin{array}{c}\text { Humus } \\
\%\end{array}$} \\
\hline & $\begin{array}{l}0.002- \\
0.006\end{array}$ & $\begin{array}{l}0.006- \\
0.02\end{array}$ & $\begin{array}{l}0.02- \\
0.06\end{array}$ & $\begin{array}{l}0.06- \\
0.2\end{array}$ & $\begin{array}{l}0.2- \\
0.6\end{array}$ & $>0.6 \mathrm{~mm}$ & \\
\hline 49.5 & 19.0 & 8.1 & 14.7 & 6.2 & 2.0 & 0.5 & 4.5 \\
\hline
\end{tabular}

The soil was gently passed through a $6 \mathrm{~mm}$ sieve and samples of approximately 25 grams were placed evenly in weighed petri-dishes which were immediately covered to prevent evaporation. The dishes and soil were weighed again and the amount of soil was reweighed to exactly 25 grams of field-moist soil. Representative subsamples were taken for determining the moisture content of the soil.

The first aggregation analysis was made with a series of six samples at their field-moist condition. Three of the samples were wetted with a fine spray and the other three by immersion. The rest of the samples were allowed to dry by removing the covers of the petri-dishes for part of the time between the analyses. The drying process was controlled by weighing the samples occasionally. Six series of samples were analyzed during the drying process from field-moist condition to air-dry condition. The exact moisture content of each sample was determined by weighing just before analysis. 
Aggregate analyses were made with a wet sieving apparatus consisting of six series of sieves with openings $2.0,0,6$ and $0.2 \mathrm{~mm}$. The sieving machine is powered by an electric motor which has a speed of 30 r.p.m. through a reduction gear. The stroke length of sieves ( 4 inches in diameter and 2 inches high) was set at $1 \frac{1}{2}$ inches.

The three samples in each analysis, which were to be wetted by spraying were placed on the uppermost sieves which were kept above the water surface and the spraying was done for 13 minutes $(1+1+1+1+1+3=8$ minutes with $5 \times 1$ min. intervals) with an atomizer producing a very fine mist. The amount of water used was about $20 \mathrm{ml}$ per sample. After wetting the sieves were slowly lovered below the water surface and the other three samples were carefully poured on the sieves. The samples were kept submerged for 20 minutes and sieved for 30 minutes.

Table 1. The results of aggregate analyses on muddy clay soil at moisture conditions varying from fieldmoist to air-dry before wetting the soil for analysis.

\begin{tabular}{|c|c|c|c|c|c|}
\hline $\begin{array}{l}\text { Sample } \\
\text { No. }\end{array}$ & $\begin{array}{c}\text { Initial soil } \\
\text { moisture } \\
\text { content } \\
(\%)\end{array}$ & $\begin{array}{l}\text { MWDA } \\
(\mathrm{mm})\end{array}$ & $\begin{array}{c}\text { Sample } \\
\text { No. }\end{array}$ & $\begin{array}{c}\text { Initial soil } \\
\text { moisture } \\
\text { content } \\
(\%)\end{array}$ & $\begin{array}{c}\text { MWDA } \\
(\mathrm{mm})\end{array}$ \\
\hline \multicolumn{3}{|c|}{ Spray wetted } & \multicolumn{3}{|c|}{ Immersion wetted } \\
\hline 1 & 34.6 & 1.56 & 4 & 36.7 & 1.52 \\
\hline 2 & 34.6 & 1.35 & 5 & 36.7 & 1.35 \\
\hline 3 & 34.6 & 1.60 & 6 & 36.7 & 1.54 \\
\hline 7 & 26.8 & 1.36 & 10 & 27.8 & 0.94 \\
\hline 8 & 27.0 & 1.29 & 11 & 27.8 & 1.21 \\
\hline 9 & 26.6 & 1.79 & 12 & 27.6 & 0.89 \\
\hline 13 & 21.2 & 1.41 & 16 & 22.1 & 0.89 \\
\hline 14 & 21.1 & 1.51 & 17 & 22.2 & 0.85 \\
\hline 15 & 20.9 & 1.44 & 18 & 22.1 & 0.82 \\
\hline 19 & 14.9 & 1.40 & 22 & 16.1 & 0.75 \\
\hline 20 & 15.1 & 1.41 & 23 & 16.0 & 0.72 \\
\hline 21 & 15.1 & 1.41 & 24 & 16.0 & 0.66 \\
\hline 25 & 7.3 & 1.24 & 28 & 8.2 & 0.59 \\
\hline 26 & 7.2 & 1.33 & 29 & 7.9 & 0.66 \\
\hline 27 & 7.3 & 1.46 & 30 & 8.4 & 0.64 \\
\hline 31 & 3.2 & 1.41 & 34 & 2.2 & 0.52 \\
\hline 32 & 3.1 & 1.49 & 35 & 1.7 & 0.54 \\
\hline 33 & 3.1 & 1.24 & 36 & 2.4 & 0.59 \\
\hline
\end{tabular}




\section{Results and discussion}

The results of the aggregate analyses made using two different wetting methods from samples at decreasing soil moisture conditions, varying from field-moist to air-dry, are given as the values of the mean weight diameter of aggregates (MWDA) in table 1 . The linear and curvilinear regressions concerning the treatments are given in table 2 and the regression lines in Fig. 1.

Table 2. The linear and curvilinear regressions of the mean weight diameter of aggregates (Y, mm) after two different wetting procedures on the initial soil moisture content $(\mathrm{X}, \%),(\mathrm{r}=$ correlation

coefficient; $\mathrm{F}_{c}=$ significance of curvilinearity; significance levels $5^{*}, 1^{* *}$ and $0.1^{* * *}$ per cent.)

\begin{tabular}{|c|c|c|c|c|}
\hline $\begin{array}{l}\text { Regr. } \\
\text { No. }\end{array}$ & Wetting method & Regressions & $\mathrm{r}$ & $\mathrm{F}_{c}$ \\
\hline $\begin{array}{l}1 \\
2\end{array}$ & Spraying $\}$ & $\begin{array}{l}Y=1.341+0.0048 \mathrm{X} \\
\mathrm{Y}=1.343+0.0045 \mathrm{X}+0.000011 \mathrm{X}^{2}\end{array}$ & $\begin{array}{l}0.408 \\
0.408\end{array}$ & 0.0014 \\
\hline $\begin{array}{l}3 \\
4\end{array}$ & Immersion $\}$ & $\begin{array}{l}\mathrm{Y}=0.399+0.0251 \mathrm{X} \\
\mathrm{Y}=0.579-9.0046 \mathrm{X}+0.000775 \mathrm{X}^{2}\end{array}$ & $\left.\begin{array}{l}0.923^{* * *} \\
0.971^{* * *}\end{array}\right\}$ & $23.60^{* * *}$ \\
\hline
\end{tabular}

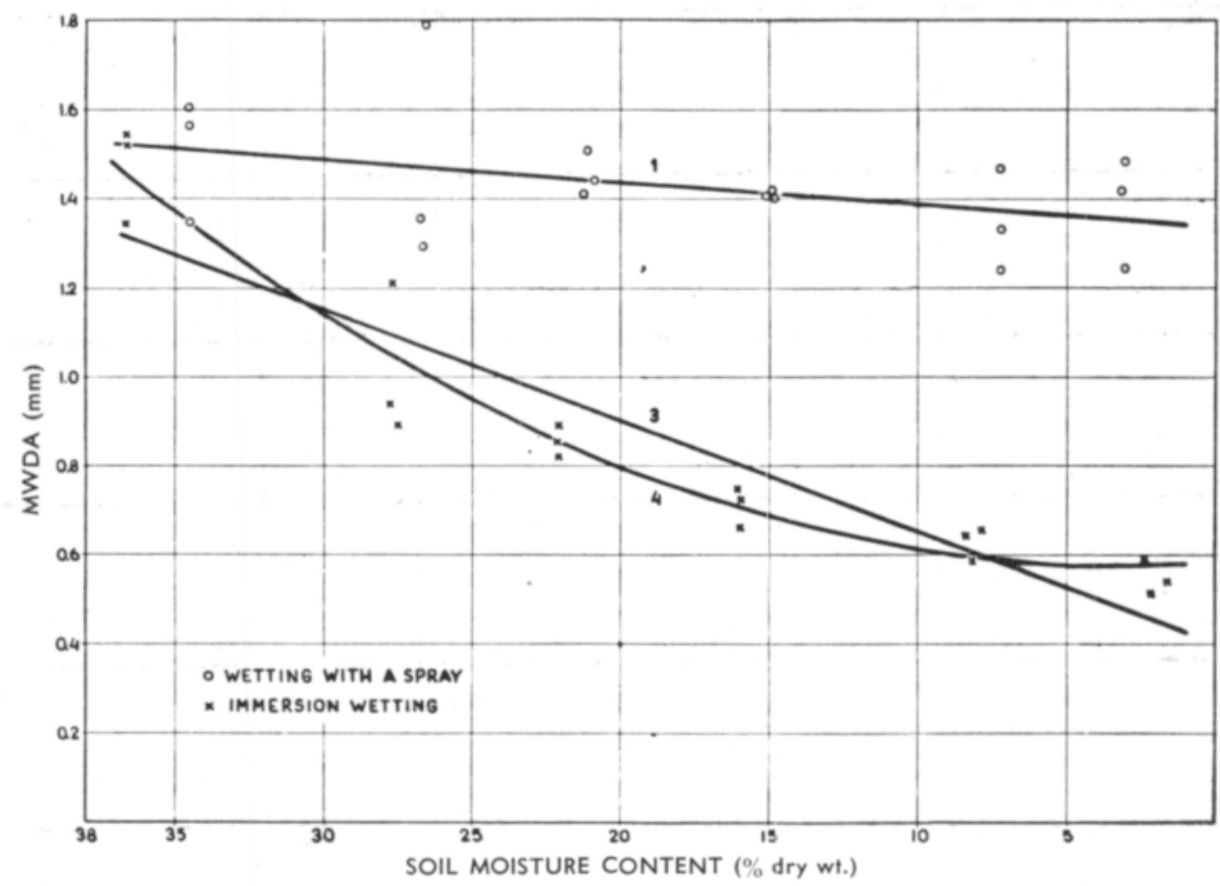

Fig. 1. The effect of initial soil moisture content on the results of aggregate analysis by the wet sieving method after two different wetting procedures. (Concerning regression numbers see table 2). 
Regressions 1 and 2 and the low r-coefficients indicate that when the soil samples are wetted slowly, by spraying a fine mist on the samples, the results of wet sieving analyses are practically independent of the initial moisture condition of the soil samples. Concerning these regressions the difference between linearity and curvilinearity is also negligible $\left(\mathrm{F}_{c}=0.0014\right)$. As the curvilinear regression line nearly joins the linear one it is excluded from Fig. 1.

When the samples are wetted by direct immersion the results of the aggregate analyses are essentially dependent on the soil moisture condition before immersion, i.e. on the magnitude of the change in moisture content in wetting (regressions 3 and 4). The correlation between MWDA and the initial moisture content is highly significant. The MWDA-values obtained are of the same degree of magnitude independent of the wetting method used if the moisture content of soil before analysis is relatively high but decreases to less than half of the above values when the soil samples are air-dried and re-wetted by immersion. This decrease seems to be somewhat stronger at higher moisture contents as is indicated by the better fit of the curvilinear regression (4) than that of the linear one $(3)\left(\mathrm{F}_{c}=23.60^{* * *}\right)$. The extremely high $\mathrm{F}$-value of the heterogeneity test between the regressions 1 and $3\left(\mathrm{~F}_{h}=28.82^{* * *}\right)$ stresses the difference in the effects of wetting treatments.

Because the initial moisture status of soil before aggregate analysis had very little influence on the MWDA-values obtained when the samples were wetted by spraying it seems apparent that the effect of air-drying is relatively small but the decrease in aggregation often found when air-dried soil samples are analyzed, is more likely due to the re-wetting treatment. This effect is very clear in the present investigation when the samples are wetted by immersion. The fact that the destruction effect of immersion wetting increases with decreasing soil moisture content or with increasing air content of aggregates supports the assumptions about the explosive effect of entrapped air in the aggregates which can, at least to some extent, be eliminated by wetting the soil slowly, for example with a fine spray. These results may also at least partly explain the contradictory results obtained in using air dry and field-moist soil samples when studying the seasonal variation of aggregation.

\section{$S u m m a r y$}

The effect of the soil moisture content (varying from the field-moist to airdry before re-wetting the muddy clay soil samples for aggregate analysis) on aggregation was studied. Two wetting procedures were used and compared: They were spraying samples with a fine mist and wetting them by immersion; aggregate analyses were made by wet sieving method.

The results of the aggregate analyses proved to be practically independent of the initial moisture condition of the soil samples when the samples were wetted slowly with a spray.

When wetting the samples by direct immersion the mean weight diameters of aggregates decrease with decreasing initial soil moisture content to values of less than half of those obtained from samples in their original field-moist condition $(34.6-36.7 \%$ dry wt.) or of those wetted with a spray. 
Air-drying seems to be a minor factor affecting the destruction of aggregates but the destruction effect of the sample pre-treatment may be very harmful if immersion wetting is used. This, however, can be eliminated almost completely if wetting with a fine mist is used.

\section{REFERENCES}

(1) Alderfer, R. B. 1946. Seasonal variability in the aggregation of Hagerstown silt loam. Soil Sci. 62: $151-168$.

(2) ChepIL, W. C. 1954. Seasonal fluctuations in soil structure and erodibility of soil by wind. Soil Sci. Soc. Amer. Proc. 18: 13-16.

(3) Czeratzki, W. 1957. Zur Problematik der Krümelstabilitätsmessung. Probleme der Krümelstabilitätsmessung und der Krümelbildung. Wiss. Arbeitstagung, Berlin am 10-11. Okt. 1957, Tagungsberichte 13: 85-97.

(4) EBert, D. 1957. Fragen der Krümelstabilität unter Berücksichtigung der Messmethodik. Z. Acker-u. Pfl.Bau 102: 391-408.

(5) Gish, R. E. \& Browning, G. M. 1948. Factors affecting the stability of soil aggregates. Soil Sci. Soc. Amer. Proc. 13: 51-55.

(6) Henin, S. 1939. L'influence des facteurs climatiques sur la stabilité structurale des sols de limon. Ann. Agron. 9: 301-311.

(7) Low, A. J. 1956. Improvements in the structural state of soils under leys. Outlook Agric. 1: 52-58.

(8) Nijhaven, S. D. \& Olmstead, L. B. 1947. The effect of sample pre-treatment upon soil aggregation in wet-sieve analysis. Soil Sci. Soc. Amer. Proc. 12: 50-53.

(9) PANABóke, C. R. \& QUiRK, J. B. 1957. Effect of initial water content on stability of soil aggregates in water. Soil Sci. 83: 185-195.

(10) Russel, M. B. \& Pearson, R. W. 1948. Report of the Committee of Physical Analyses of the Soil Science Society of America. Soil Sci. Soc. Amer. Proc. 13: p. 575.

(11) Show, B. T., Fergus, E. N., Lutz, F. J., McCalla, T. M. and Russel. M. B. 1948. Report of the Committee of Terminology of the Soil Science Society of America. Ibid. 13: p. 574.

(12) SillanpäÄ, M. 1958. Soil aggregation as determined by wet sieving method after different sample treatments. (Selostus: Muruanalyysistä märkäseulontamenetelmällä). Acta agr. fenn. 94/16: $20 \mathrm{p}$.

(13) Yoder, R. E. 1936. A direct method of aggregate analysis and a study of the physical nature of erosion losses. J. Amer. Soc. Agron. 28: 337-351.

S E L O T U S :

MAANÄYTTEIDEN KOSTEUSTILAN JA KOSTUTUSKÄSYTTELYN VAIKUTUKSESTA MURUANALYYSIEN TULOKSIIN

Miкко SillanPÄÄ

Maatalouden Tutkimuskeskus, Maantutkimuslaitos.

Tutkittaessa maan rakenneominaisuuksia sekä sen vaihteluita on käytetty sekä ilmakuivia että luonnonkosteita maanäytteitä. Aikaisemmat tutkimustulokset (mm. 1, 8, 12) antoivat kuitenkin aihetta tutkia maan alkuperäisen kosteustilan vaikutusta muruanalyysien tuloksiin käytettäessä menetelmiä, joissa varsinaista analyysiä edeltää maanäytteiden kostutus. 
Tutkimusta varten otettiin suuri homogeeninen liejusavinäyte, joka pidettiin luonnonkosteana tiiviissä muoviastiassa ja jaettiin esiseulonnan $(6 \mathrm{~mm})$ jälkeen 25 gramman osanäytteisiin petrimaljoihin. Petrimaljojen kansia ajoittain auki pitämällä ja haihtumisen aiheuttamaa painonvähennystä seuraamalla annettiin näytteiden kuivua alkuperäisestä kosteustilastaan ilmakuiviksi. Eri kuivumisvaiheissa suoritettiin muruanalyysejä kuuden näytteen sarjoissa. Kutakin analyysiä varten kostutettiin kolme näytettä sumuttamalla ja toiset kolme upottamalla. Muruanalyysien tulokset on ilmoitettu taulukossa 1 sekä muruisuuden riippuvuutta maan kosteustilasta kuvaavat regressiot taulukossa 2 ja kuvassa 1 .

Regressiot 1 ja 2 sekä niiden alhaiset korrelaatiokertoimet ilmaisevat muruanalyysien tuloksien olevan lähes täysin riippumattomia maan kosteustilasta ennen analyysiä, jos kostutus suoritetaan sumuttamalla. Koska kaariviivainen regressio (regr. 2) lähes täysin yhtyy suoraviivaiseen (regr. 1), ja niiden eron merkitsevyys on mitätön, on edellisen kuvaaja jätetty pois kuvasta 1 .

Sen sijaan näytteiden kost utus upottamalla alentaa muruisuutta, sitä enemmän mitä kuivempaa maa on ennen kostutusta ollut (regressiot 3 ja 4). Kaariviivaisen regression (4) voimakkaampi korrelaatio ja niiden eron merkitsevyys $\left(\mathrm{F}_{c}=23.60^{* * *}\right)$ osoittavat lisäksi kuivumisen vaikutuksen olevan suhteellisesti suuremman näytteiden kosteuden ollessa lähellä alkuperäistä luonnonkosteutta kuin kuivumisen edistyttyä pitemmälle. Regressioiden 1 ja 3 välisen heterogeenisyystestin erittäin korkea F-arvo $\left(28.82^{* * *}\right)$ korostaa vielä kostutuskäsittelyn olennaista merkitystä muruanalyysien suorittamisessa.

Koska maanäytteiden kuivattaminen aina ilmakuiviksi asti ei sanottavasti vaikuttanut muruanalyysien tuloksiin käytettäessä sumutuskostutusta, näyttäă ilmeiseltä, ettă ilmakuivia näytteitä käytettăessä usein saadut alhaiset muruisuusarvot johtuvat pikemminkin năytteiden kostutuskåsittelyn muruja hajottavasta vaikutuksesta kuin kuivatuksesta. Tämä vaikutus on erittäin voimakas kostutettaessa näytteet upottamalla. Kun hajoitusvaikutuksen voimakkuus lisäksi kasvaa maan kosteuden vähentyessä eli murujen ilmapitoisuuden kasvaessa, tukevat saadut tulokset sitä käsitystä, että murujen hajoaminen kostutettaessa suureksi osaksi johtuu murujen sisäisen ilmanpaineen muutoksesta niiden kastuessa.

Muruisuuden kausivaihteluita tutkittaessa saadut ristiriitaiset tutkimustulokset voidaan myōs ainakin osittain selittää edellä selostettujen tutkimustulosten perusteella. 